\title{
Socio-Economic and Environmental Issues in the Context of the Sustainable Development Theory of Russian Regions
}

\author{
Alexey $V$. Vasilchikov ${ }^{1}$, Oksana S. Chechina ${ }^{2}$, Svetlana A. Nikonorova ${ }^{3}$ and Maria $V$. \\ Rakhova $^{3, *}$ \\ ${ }^{1}$ Samara State Technical University, Department of Economics and Organization Management, \\ 443100 Samara region, Samara, Molodogvardeyskaya str, 244, Russian Federation \\ ${ }^{2}$ Samara State Technical University, Department of Industrial Economics and Production \\ Management, 443100 Samara region, Samara, Molodogvardeyskaya str, 244, Russian Federation \\ ${ }^{3}$ Vladimir State University named after Alexander and Nikolay Stoletovs, Department of \\ Management and Marketing, 600005 Vladimir Region, Vladimir, Gorkogo str, 79, Russian Federation
}

\begin{abstract}
Unevenness is a feature of sustainable development of Russian territories. It arises due to the impressive difference in the provision of natural resources, residents' mentality, natural and climate factors, the infrastructure that has formed over the years of territory's existence, and other various conditions. The purpose of the issue is the research of the main factors reflecting the sustainability of development of Russia and proposes directions for improving the social, economic and environmental policy of the country.
\end{abstract}

\section{Introduction}

The level of development of the economic policy and conditions provided for doing business, as well as the effective use of natural, geographical and historical advantages have a significant impact on strengthening positions of the Russian Federation's territorial parties. The idea of the regions' socio-economic position implies a set of economic and other indicators of individual regions, as well as the presence of their strengths: historical, geographical, resource or industrial. All of them directly affect the sustainable development of the region. Many authors [1] note that the level of socio-economic development of regional territories depends on factors such as:

- climate conditions, geographic location and socio-economic potential;

- uneven distribution of production forces;

- processes caused by the transition to a market type of economy with the subsequent rejection of the previously used administrative-planning system of activities;

- the prevailing characteristic features of social culture and established traditions and norms;

- federal and regional policy that solves the socio-economic issues of the regions.

* Corresponding author: mariarahova@yandex.ru 
The heterogeneity of the region's socio-economic development has led to an emphasis on sustainability approaches. The term "sustainable development» is considered by scientists on two sides. In a narrower sense, the emphasis is on environmental aspects. It is widely regarded as a harmonized, balanced growth of the subsystems of the economic, environmental and social spheres aimed at supporting and closing the demands of present and future generations. In general, the sustainable development of the region is understood to mean ensuring the stability of the social and economic components, the integrated development of productive capacities and social relations, providing a decent standard of living and self-fulfillment for the population and maintaining and optimizing the use of resources [2].

\section{Materials}

International organizations and individual countries now have some theoretical and practical experience in developing indicators of sustainable development. Indicators and their systems are quite diverse and often have a very complex system of such [3].

The first comprehensive development in this area was the system of sustainable development indicators proposed by the UN Commission on Sustainable Development in 1996. The documents adopted in 2012 within the framework of the UN Conference on Sustainable Development in Rio de Janeiro emphasized the need to monitor the progress of the transition to sustainable development and a "green" economy, to complement and move away from absolutizing traditional macroeconomic indicators. In 2015, the UN member states adopted the 2030 Agenda for Sustainable Development, which contains 17 main goals.

An analysis of the indicator's dynamics of these goals indicates insignificant positive changes in the whole of the Russian Federation in 2019 compared to 2010. However, consider some of them as of 2018-2019. Thus, the share of the population living below the national poverty line in the country - an indicator reflecting the goal of "No poverty" decreased by $0.3 \%$. The Good health and well-being goal is characterized by a gradual decrease in maternal and child mortality rates by $1.1 \%$ and $4.76 \%$, respectively, in 2019 , a decrease in the incidence of tuberculosis and hepatitis by $7.1 \%$, and reduction in deaths from suicide, road traffic accidents and poisoning. As it can be seen in Table 1, the indicators of the "Decent work and economic growth" goal have negative trends by 2019, the GDP physical volume index is decreasing, while the share of informal employment is growing and the unemployment rate is slightly decreasing. The "Industry, innovation and infrastructure" goal is characterized by a positive trend in the indicators of added value and employment in the "Manufacturing" industry.

Let's clarify that the dynamics of most economic and social indicators in 2020 worsened due to the COVID-19 pandemic.

According to Rosstat, in 2020, the natural population decline in Russia compared to 2019 increased by 2.2 times and amounted to 688.7 thousand people, and for the same period of 2019 - 316 thousand people. The number of deaths in January-December 2020 was 2.124 million and increased by $18 \%$ compared to 2019 [6]. The decline in industrial production in general for 2020 was $2.9 \%$ [7]. The strongest decline in output was in the extraction of nonmetallic minerals $(-15.4 \%)$, the automotive $(-11.6 \%)$ and leather $(-12.4 \%)$ industries, oil and gas production $(-8.1 \%)$, coal $(-6.3 \%)$, production of coke and petroleum products $(-3 \%)$, metallurgical production $(-2.4 \%)$. The maximum growth in 2020 , as expected, was shown by the production of drugs and medical materials $(+23 \%)$, textiles $(+$ $8.9 \%)$, chemical production $(+7.2 \%)$, rubber and plastic products $(+3,2 \%)$, food production $(+3.5 \%)[8]$. 
Table 1. Russian Federation's Sustainable Development Goal indicators [4, 5].

\begin{tabular}{|l|r|r|r|r|r|r|}
\hline \multicolumn{1}{|c|}{ Indicators } & $\mathbf{2 0 1 0}$ & $\mathbf{2 0 1 5}$ & $\mathbf{2 0 1 6}$ & $\mathbf{2 0 1 7}$ & $\mathbf{2 0 1 8}$ & $\mathbf{2 0 1 9}$ \\
\hline $\begin{array}{l}\text { Proportion of population living below the national } \\
\text { poverty line in the year preceding the previous year, } \\
\text { \% }\end{array}$ & 12,5 & 13,4 & 13,2 & 12,9 & 12,6 & 12,3 \\
\hline Maternal mortality rate per 100,000 live births & 16,5 & 10,1 & 10,0 & 8,8 & 9,1 & 9,0 \\
\hline Under-five mortality rate per 1,000 live births & 9,9 & 8,0 & 7,4 & 6,9 & 6,3 & 6,0 \\
\hline Incidence of tuberculosis. per 100,000 population & 76,9 & 57,7 & 53,3 & 48,3 & 44,4 & 41,2 \\
\hline $\begin{array}{l}\text { Incidence of hepatitis B, per 100,000 population } \\
\text { Index of the volume of gross domestic product per } \\
\text { capita for the year preceding the previous year, \% }\end{array}$ & 15,4 & 11,9 & 11,1 & 10,4 & 9,9 & 9,2 \\
\hline $\begin{array}{l}\text { Share of informal employment in the non- } \\
\text { agricultural sector, \% }\end{array}$ & 104,5 & 97,8 & 100,0 & 101,7 & 102,5 & 101,4 \\
\hline $\begin{array}{l}\text { Unemployment rate, \% } \\
\text { Unem }\end{array}$ & 7,0 & 16,2 & 16,6 & 16,7 & 16,9 & 17,4 \\
\hline Added value share of manufacturing & 5,6 & 5,5 & 5,2 & 4,8 & 4,6 \\
\hline $\begin{array}{l}\text { in the year preceding the previous gross domestic } \\
\text { product of the Russian Federation, \% }\end{array}$ & 14,9 & 13,8 & 13,0 & 13,7 & 14,4 & 14,6 \\
\hline $\begin{array}{l}\text { per capita for the year preceding the previous, } \\
\text { rubles }\end{array}$ & 41545 & 70275 & 68296 & 77011 & 92840 & 98165 \\
\hline Ratio of development rate to population growth rate & 0,98 & 1,01 & 0,94 & 0,99 & 0,96 & 1,06 \\
\hline
\end{tabular}

Monitoring achievements of indicators' sustainable development goals is not the only method for assessing the state of the country. Various state and public organizations, research institutes and rating agencies in Russia carry out the formation of ratings assessing various socio-economic and environmental aspects of development. So, experts of the rating agency "RIA Rating" annually, starting from 2013, compiled a rating of the Russian Federation regions in terms of quality of life. Since 2012, the Institute of Statistical Studies and Economics of Knowledge of the National Research University "Higher School of Economics" has been compiling the rating of innovative development of the Russian Federation. Since 2000, Interfax-ERA has been compiling ratings of fundamental environmental and energy efficiency . In turn, a fairly voluminous ecological and economic index of the regions is compiled by the World Wide Fund for Nature WWF Russia. The ecological situation in the regions of the Russian Federation and the ecological and economic sustainability of their development are reflected when calculating the indicators of this index. Since 2008, the environmental rating of the constituent entities of the Russian Federation has been published four times a year, which is being developed by the Green Patrol Public Organization with the support of the Presidential Grants Fund. The goal of the project is to carry out public monitoring and a comparative assessment of the regions of the Russian Federation in the field of environmental safety and environmental protection [9].

In general, comparing all the listed methods and ratings, the main criteria for sustainable development can be called:

- a decent level of quality of life of the region' residents and their protection;

- best built structure of the economy and the effectiveness of its application;

- social balance;

- maintaining balance in environmental issues;

- providing a variety of promising conditions for the life support of future generations.

In the analysis of factors of sustainable development materials on such criterion as «a decent standard of living of residents of regions and their protection» appeared interesting. It should be recalled that article 7 of the Constitution of the Russian Federation explicitly 
states that «The Russian Federation is a social State whose policy is aimed at creating conditions that ensure a decent life and free human development» [10]. Therefore, the indicator «quality of life» is the resulting assessment of the level of social and economic development in the formulation and implementation of state policy in the sphere of economic security [11].

The rating agency National Credit Ratings, commissioned by RosBusinessConsulting, prepared a rating of Russian regions for 2019 in terms of the population's quality of life. The top ten outsider regions included highly subsidized and sparsely populated territories of Far East and Eastern Siberia, as well as two republics of North Caucasus. At the top of the list are St. Petersburg (7), Moscow (6.1), Belgorod region (5.64), Moscow region (5.61) and Voronezh region. (5.31). This rating is an attempt to rank regions not by traditional indicators of economic potential or investment activity, but by a number of indicators that affect the standard of life of Russians living in a particular area [12].

Research has also highlighted one of the most troubling contemporary issues "maintaining a balance in environmental issues." This problem is acute, since it is quite obvious that the ecological balance is disturbed. This is caused by the modern level of development of the industrial sector, as well as the insufficiently thoughtful introduction of all kinds of innovative technologies, which, with all the positive aspects, unfortunately, very strongly contribute to the destruction of the ecological balance, which negatively affects the ecological situation in the regions and the country as a whole.

What is happening now with the environment around the world, without exaggeration, can be described as a socio-ecological crisis. The balance between natural factors and human activity is almost completely violated. And the degree of this violation is very different in terms of the consequences for the whole world.

According to the WWF Living Planet Report 2020 the global Living Planet Index continues to decline. It shows an average $68 \%$ decrease in population sizes of mammals, birds, amphibians, reptiles and fish between 1970 and 2016. A 94\% decline in the LPI for the tropical sub regions of the Americas is the largest fall observed in any part of the world. Data from the United Nations Environment Programme shows that, per person, our global stock of natural capital has declined by nearly $40 \%$ since the early $1990 \mathrm{~s}$, while produced capital has doubled and human capital has increased by 13\%. But too few of our economic and financial decision-makers know how to interpret what we are hearing, or, even worse, they choose not to tune in at all [13].

The thoughtless behavior of people in relation to the environment leads to an ecological disaster. There are many reasons for the violation of the ecological balance:

- large-scale construction of housing in cities, which is associated with deforestation;

- an increase in the number of vehicles, which contributes to the accumulation of smog and carbon dioxide (which in turn provokes an increase in the incidence of diseases among citizens);

- lack of effective ways of separating waste and production facilities for their processing;

- poorly developed introduction of waste-free production, etc.

In Russia, over the period of 2010 to 2019 (Table 2), there is a gradual decrease in the negative impact on the environment, which, according to scientists, is not enough to maintain biological balance. In the Russian Federation, for the period of 2010 to 2019, there is an average annual decrease in water intake from natural sources $(-1.7 \%)$, discharge of polluted wastewater $(-2.95 \%)$, emissions of pollutants into the air from stationary sources ($1.1 \%$ ). At the same time, the volume of emissions of pollutants from mobile sources annually increases by an average of $1.7 \%$, and the volume of production and consumption waste by $8.5 \%$, meaning that in just 10 years the amount of this waste has more than doubled. Both current and capital expenditures for environmental protection increase 
significantly every year, however, it is necessary to take comprehensive measures to protect the environment.

Table 2. Russian Federation's Sustainable Development Goal indicators [14].

\begin{tabular}{|l|r|r|r|r|r|r|}
\hline \multicolumn{1}{|c|}{ Indicators } & $\mathbf{2 0 1 0}$ & $\mathbf{2 0 1 5}$ & $\mathbf{2 0 1 6}$ & \multicolumn{1}{c|}{$\mathbf{2 0 1 7}$} & \multicolumn{1}{c|}{$\mathbf{2 0 1 8}$} & \multicolumn{1}{c|}{$\mathbf{2 0 1 9}$} \\
\hline $\begin{array}{l}\text { Water withdrawal from natural } \\
\text { water bodies for use, billion } \mathrm{M} 3\end{array}$ & 69,7 & 68,0 & 61,3 & 59,8 & 59,7 & 59,6 \\
\hline $\begin{array}{l}\text { Discharge of contaminated } \\
\text { wastewater, billion } \mathrm{M} 3\end{array}$ & 16,5 & 14,4 & 14,7 & 13,6 & 13,1 & 12,6 \\
\hline $\begin{array}{l}\text { Emissions of pollutants into the } \\
\text { atmosphere air, thousand tons }\end{array}$ & 32353 & 31269 & 31617 & 32068 & 32327 & 32735 \\
\hline from stationary sources & 19116 & 17296 & 17349 & 17477 & 17068 & 17295 \\
\hline from mobile sources & 13237 & 13973 & 14268 & 14591 & 15259 & 15440 \\
\hline $\begin{array}{l}\text { Production and consumption } \\
\text { waste generation, mln.tons }\end{array}$ & 3735 & 5060 & 5441 & 6221 & 7266 & 7751 \\
\hline $\begin{array}{l}\text { Current expenditures for } \\
\text { environmental protection } \\
\text { (million rubles) }\end{array}$ & $\mathbf{2 . .}$ & 292074 & 306534 & 320947 & 345464 & 374411 \\
\hline
\end{tabular}

In order to successfully address the issues of ecological balance, it is of course necessary for every resident of the planet to understand that it is his/her behavior in relation to nature, in the home or in the workplace that determines the overall state of the environment.

According to a poll by the All-Russian Public Opinion Research Center (VTsIOM) conducted on July 26 and October 11, 2020, the following results were obtained. According to the study, more than half of the respondents (54\%) believe that over the past two or three years, the environmental situation in the world has rather worsened, almost the same number of citizens (53\%) expressed this opinion in relation to Russia, while $48 \%$ of Russians noted that in their region the ecological situation has not changed. It is noted that almost half of the citizens (47\%) assess the environmental situation in the world at three points out of five, where five is "very good" and one is "very bad"; the respondents rated the ecology in Russia at the same level (44\%) and in the regions (32\%). According to the survey, the most pressing environmental problems for their region, from the proposed list, Russians chose pollution of the banks of urban and surrounding water bodies (44\%), pollution of urban and surrounding water bodies with garbage $(43 \%)$, pollution of urban and surrounding water bodies with industrial and sewage effluents and illegal logging activities (37\% each, respectively), unauthorized dumps within the settlement and in the immediate vicinity of it (35\%), air pollution from car exhaust $(32 \%)$, forest fires $(31 \%)$. A telephone survey was conducted with 1,600 Russians aged 18 and over [15].

In the context of improving the environment in the country, the Ministry of Natural Resources and Ecology launched the national project «Ecology» in 2019. The aim of the project is a radical improvement in the environmental situation and a positive impact on the health of Russians. Authorities, implementers, curators of federal projects, social organizations and citizens participate in this multilateral work. The national project includes nine federal projects. Work is carried out in five areas: waste, water, air, biodiversity, technology The duration of the national project is until 31 December 2024 [16]. For their part, various social organizations and voluntary movements are not immune to social and environmental concerns. For example, the All-Russian public movement "People's Front "For Russia" together with the "Youth of the UNF" implements such projects as : the Center for Public Monitoring of the ONF on Ecology and Forest Protection, the Center for Monitoring the Improvement of the Urban Environment, Ecocare, "Map of landfills" and "Map of dead roads" [17]. In turn, the young generation of this 
movement helps with implementing ecological actions "Save the forest", "Live, forest", etc. [18].

For their part, various social organizations and voluntary movements are not immune to social and environmental concerns. For example, the All-Russian public movement "People's Front "For Russia" together with the "Youth of the UNF" implements such projects as : the Center for Public Monitoring of the ONF on Ecology and Forest Protection, the Center for Monitoring the Improvement of the Urban Environment, Ecocare, "Map of landfills" and "Map of dead roads" . In turn, the young generation of this movement helps with implementing ecological actions "Save the forest", "Live, forest", etc. In 2008 in Estonia, and 10 years later in Russia, the civil project "Let's Do It!" was launched. Its goal is to unite society, government, business and the media into one team to cleanse nature from garbage and preserve cleanliness. In 2020 , about $5 \%$ of the population of the Russian Federation took part in cleaning, which, of course, draws attention to the problems of garbage, reducing consumption, introducing saving technologies, separate collection and increasing social responsibility.

It is important to note that considering the socio-economic situation of the regions in the context of the theory of sustainable development, the issue of social balance is also relevant, which ensures the reduction of social tension. In this regard, it is important to emphasize that the social structure of each region of the country directly depends on the employment of citizens; it is a well-thought-out policy of providing the population with jobs, on the one hand, is a prerequisite for the financial stability of citizens, on the other hand, it forms a balanced structure of jobs in all types of economic activity and accordingly reduces the degree of social tension in society.

Regional job security programs should take into account:

- the need for specialists,

- opportunities for their retraining,

- the use of all types of support (provision of local benefits, subsidies, concessional lending, etc.).

The implementation of the programs should contribute to the development of small and medium-sized businesses, as well as the development of youth entrepreneurship.

Considering the problem of social balance, it is important to emphasize that, in addition to providing the population with jobs, it is necessary to strategically develop such areas as:

- support of youth progressive initiatives,

- expanding the availability of social services (healthcare, education, cultural and leisure organization) on the basis of continuous improvement of the quality of these services,

- improvement of housing conditions through the introduction of mortgage lending programs, taking into account the living standards of the citizens of the region.

The socio-economic situation of the regions directly depends on the activities of the younger generation. Young people are the future of the country, and not only the development of the regional economy, but also the intellectual potential of the country as a whole depends on their starting positions. The fundamental moment at the start of the activity of the young generation is their provision of jobs.

According to the website "Statistics and Indicators. Regional and federal ", which considered the distribution of unemployment depending on the age of a particular person, regardless of the period, it was noted that:

- the situation was worst among young people under the age of 20 - here each third experienced problems. Thus, the statistics here indicate that $30 \%$ of citizens are in constant search of employment. This can be attributed, first of all, to the fact that young people do not have a certain qualification, since at this age, in the overwhelming majority of cases, they are just finishing school. 
- then the situation looked unfavorable among citizens aged 20 to 24 years of age- on average about $10 \%$ [19].

In analyzing the data presented above, it should be noted that the «collapse» of the youth labor market is due to the following reasons:

- first, the Russian economy is in a constant decline in growth rates, which results in an excess of the reduction in the number of jobs over the newly created ones.

- second - the consequences of the 2018 pension reform are beginning to manifest, namely: older people are detained in the labor market, according to the law, they are not subject to dismissal. Their number has increased in 1 year from 250 thousand to 700 thousand people.

The impact of government processes is directly reflected in regions. At the same time, the basis of formation is economic activity, which determines the level of quality of life of residents and social sphere, the probability of reducing the use of resources of the surrounding world and the presence of opportunities for future generations.

In building sustainable development, priority should be given to ensuring security and comfort in every sphere of life, namely, an economic indicator such as quality, which affects all spheres of life. Quality of life is a key area that makes it possible to achieve the social and economic security of the government, as well as the formation of its scientific, technical and human potential.

That is why workers' wages have a great influence on the development of regions and contribute to their inequality. It determines whether the population can afford the necessary food, services and recreational expenses. If wages in the regional territory are high, the number of people wishing to live there increases significantly. There is an influx of people seeking employment, the labor market is improving, the skills of staff are increasing in response to competition, and the production activities and tax budget of the region are increasing. The situation is reversed if wages in the region are significantly lower: people are leaving the territory, poverty and crime are on the rise, productive activities are slow and the economy is significantly affected.

Investing in human potential, which includes spending on education and training, health authorities and maintaining the physiological active component of the inhabitants of the regions, is one of the most promising, as it contributes to the health and potential of citizens.

\section{Conclusion}

The priority nature of the socio-economic development of the region determines the sustainability of this development, since stability, constancy of all directions allows to strengthen social relations, systematically raise the role of productive forces, positively contribute to the moral and spiritual development of the population, provide opportunities for increasing human capital, rationally use natural and other types of resources.

Thus, the main indicators of sustainability of the socio-economic and environmental development of regions are: a decent quality of life of citizens and their safety; a wellfunctioning mechanism of interaction between all sectors of the economy; equal opportunities to meet all the vital needs of every member of the society, regardless of age, sex, status, nationality, religion and other characteristics; positive trends in the environmental component. The combination of these indicators provides, with their harmonious combination, a decent standard of living for people in the present and creates a platform for future generations. Of course, the stability of the country's socio-economic development as a whole is of decisive importance in this. 


\section{References}

1. Ayvazian. S. A.. Afanasiev, M. Yu.3 \& Kudrov. A. V. (2018). Indicators of Regional Development Using Differentiation Characteristics. Montenegrin Journal of Economics. 14(3). 7-22.

2. Y.Bychenko, Innovative Mechanism for Sustainable Human Capital Development, LAP Lambert Academic Publishing (2018)

3. S.N. Bobylev Ecological and economic index of the regions of the Russian Federation WWF Russia, RIA Novosti (2012)

4. Russia in numbers. 2020: Brief statistics collection, Rosstat, M, (2020).

5. Official statistics of Rosstat https://rosstat.gov.ru/folder/10705

6. https://rosstat.gov.ru/storage/mediabank/TwbjciZH/edn12-2020.html

7. https://rosstat.gov.ru/folder/313/document/112098?print=1

8. https://rg.ru/2021/01/25/rosstat-ocenil-snizhenie-proizvodstva-v-2020-godu.html

9. https://irsup.hse.ru/ratingsinfo

10. The Constitution of the Russian Federation "(adopted by popular vote on 12.12.1993 with amendments approved during a nationwide vote on 01.07.2020)

11. Presidential Decree of May 13, 2017 № 208 "About the Economic Security Strategy of the Russian Federation for the period till 2030" http://www.garant.ru/products/ipo/prime/doc/71572608

12. https://www.rbc.ru/economics/21/07/2020/5f0ece439a79470d37b66efc

13. WWF Living Planet Report 2020 - Bending the curve of biodiversity loss. Almond, R.E.A., Grooten M. and Petersen, T. (Eds). WWF, Gland, Switzerland (2020)

14. https://rosstat.gov.ru/folder/11194

15. https://ria.ru/20201130/ekologiya-1586883113.html

16. https://ecologyofrussia.ru/proekt/

17. https://onf.ru/projects/

18. https://molodezhka.onf.ru/projects/

19. https://rosinfostat.ru/uroven-bezrabotitsy/\#i-7] 